\title{
Ulser Traumatik Akibat Rotasi dan Migrasi Gigi
}

\author{
Mila Umayah ${ }^{1}$ Atia Nurul Sidiqa ${ }^{2}$ \\ ${ }^{1}$ Program Pendidikan Profesi Dokter Gigi, Program Studi Kedokteran Gigi, Fakultas \\ Kedokteran, Universitas Jenderal Achmad Yani \\ ${ }^{2}$ Departemen Material Kedokteran Gigi, Program Studi Kedokteran Gigi, Fakultas \\ Kedokteran, Universitas Jenderal Achmad Yani
}

E-mail: milaaumy@yahoo.com, atia.nurul@lecture.unjani.ac.id

\begin{abstract}
ABSTRAK
Ulser merupakan salah satu lesi pada mukosa mulut yang umum terjadi pada individu. Ulser traumatik adalah manifestasi rongga mulut yang menyebabkan kehilangan lapisan terluar dari kulit atau mukosa akibat trauma. Ulser dapat disebabkan oleh trauma mekanik akibat malposisi gigi, bahan aktif kimia, respon elektrik, perubahan suhu. Pasien laki-laki, 59 tahun mengalami sariawan pada bagian pinggir lidah sebelah kanan sejak kurang lebih 1 minggu yang lalu. Pada pemeriksaan intraoral ditemukan ulser pada ventral lidah dextra dengan ukuran $5 \mathrm{x} 3 \mathrm{~mm}$, permukaan ditutupi oleh pseudomembran putih kekuningan, dikelilingi oleh daerah eritema dan tidak beraturan. Terapi yang diberikan berupa non farmakologi dan farmakologis. Ulkus yang disebabkan oleh malposisi gigi umumnya terjadi pada mukosa yang berhadapan dengan gigi yang mengalami malposisi seperti pada bibir, lidah, dan bukal. Iritasi mekanis terjadi ketika suatu benda yang lebih keras bergesekan secara terus menerus pada mukosa. Ulser traumatik yang terjadi pada pasien dikarenakan trauma mengenai gigi yang mengalami rotasi dan migrasi sehingga menimbulkan cedera pada jaringan lunak. Pada kasus ini ulkus traumatik pada ventral lidah kanan karena trauma mengenai gigi yang mengalami rotasi dan migrasi. Penatalaksanaan terapi non farmakologi dan farmakologi. Lesi di evaluasi selama 2 minggu, lesi di nyatakan sembuh dan dan bekas ulkus tidak terlihat.
\end{abstract}

Kata Kunci : ulkus, trauma, rotasi, migrasi, malposisi 


\begin{abstract}
Ulcer is one of the most common oral mucosal lesions. Traumatic ulcers are oral manifestations with the loss of the outer layer of mucosa due to trauma. Ulcers can be caused by mechanical such as malposition, chemical, electrical response, and temperature changes. Male, 59 years old, had thrush on the right side of the tongue since about 1 week ago. On intraoral examination, an ulcer on the ventral right tongue with a size of $5 \times 3 \mathrm{~mm}$, the surface is covered by yellowish white pseudomembrane, surrounded by erythematous and irregular areas. The therapy given is in the form of non-pharmacological and pharmacological. Ulcers caused by malpositioned teeth generally occur on the mucosa opposite the malpositioned teeth such as the lips, tongue, and buccal. Mechanical irritation occurs when a harder object continuously scratch against the mucosa. Traumatic ulcers that occur in patients are caused by trauma to the teeth that undergo rotation and migration, causing injury to the soft tissues. In this case a traumatic ulcer on the ventral right tongue due to trauma to the teeth that underwent rotation and migration. Management of non-pharmacological and pharmacological therapies. The lesion was evaluated for 2 weeks, the lesion was declared healed and the ulcer was not visible.
\end{abstract}

Keywords : ulcus, trauma, rotation, migration, malposition 


\section{PENDAHULUAN}

Lesi pada rongga mulut adalah salah satu kelainan yang banyak ditemukan pada praktek dokter gigi. Diantara adalah kasus ulser traumatik pada mukosa. Ulser trauma dapat berupa kelainan akut maupun kronis. Gambaran klinis ulser traumatik bervariasi dan sebagian besar penyebab dan efeknya dapat ditentukan dengan anamnesis dan pemeriksaan klinis yang menyeluruh. Meskipun biopsi pada lesi tersebut tidak diperlukan namun pemeriksaan histologis dapat dilakukan sebagai pemeriksaan penunjang ${ }^{1}$. Ulser traumatik adalah manifestasi rongga mulut yang menyebabkan kehilangan lapisan terluar dari kulit atau mukosa akibat trauma ${ }^{2}$.

Maloklusi merupakan salah satu masalah kesehatan gigi dan mulut yang dapat mempengaruhi penampilan wajah (estetika) dan status sosial pasien. Penelitian epidemiologis menunjukkan bahwa setidaknya $70 \%$ dari populasi mengalami maloklusi 3. Insidensi ulkus traumatik pada pasien yang menggunakan piranti ortodonsia cekat lebih tinggi daripada pasien dengan alat ortodonsi lepasan ${ }^{4}$.

Ulser traumatik pada rongga mulut dapat disebabkan oleh trauma seperti trauma mekanis, yang paling sering adalah karena tergigit, iritasi gigi tiruan yang tidak dirawat, dan terkena bagian gigi atau makanan yang tajam. Gambaran klinis ulser traumatik bentuknya tidak spesifik tergantung pada etiologinya, namun pada umumnya margin ulser ireguler, permukaan ditutupi pseudomembran, ukuran bervariasi yaitu dari beberapa milimeter hingga beberapa sentimeter. Ulser traumatik lebih sering terjadi pada mukosa bukal $(42 \%)$, lidah $(25 \%)$, dan mukosa labial bawah $(9 \%)^{5}$. Pemeriksaan mukosa mulut yang cermat merupakan faktor terpenting untuk menentukan diagnosis sementara. Usia, jenis kelamin, dan riwayat gigi dan medis pasien dapat memberikan informasi yang bermanfaat. Pemeriksaan meliputi jumlah, bentuk, ukuran, dan lokasi lesi juga harus diamati dengan cermat ${ }^{6}$. Ulkus traumatik disebabkan oleh mekanik, termal, atau iritasi kimia. Penyebab paling sering adalah gigi palsu yang tidak adaptasi, mahkota atau jembatan bermata tajam, dan kerusakan gigi ${ }^{7}$.

Penanganan terhadap ulser traumatik yang utama adalah menghilangkan penyebab trauma. Ulser traumatik akan sembuh dalam 6-10 hari setelah trauma dihilangkan. Penyembuhan ulser dapat terjadi secara spontan, namun topikal steroid dapat membantu mempercepat penyembuhan dan mengurangi gejala inflamasi ${ }^{8,9}$.

\section{LAPORAN KASUS}

Seorang pasien laki-laki berusia 59 tahun datang ke Rumah Sakit Gigi dan Mulut Pendidikan (RSGMP) Unjani dengan keluhan terdapat sariawan pada bagian pinggir lidah sebelah kanan belakang sejak sekitar 1 minggu yang lalu. Sariawan terasa nyeri pada saat pasien berbicara ataupun makan makanan. Pasien mengaku tidak memiliki riwayat sariawan berulang. Pasien belum mengobati sariawannya.

Pemeriksan ekstraoral ditemukan wajah simetris dengan kelainan pada sendi TMJ berupa kliking di sebelah kiri. Pemeriksaan intraoral kebersihan mulut pasien sedang, kehilangan gigi 16, 15, 14, 13, 12, 11, 21, 22, 23, 24, 25, 26, 27, 36, 35, 34, 33, 32, 31, 
41, 42, 45, 45, dan 47, linguoversi disertai diastema gigi 43 dan 44, tampak ulser pada ventral lidah dextra dengan ukuran $5 \mathrm{~mm}$ x $3 \mathrm{~mm}$, permukaan ditutupi oleh pseudomembran putih kekuningan, dikelilingi oleh daerah eritema dan tidak beraturan (Gambar 1).

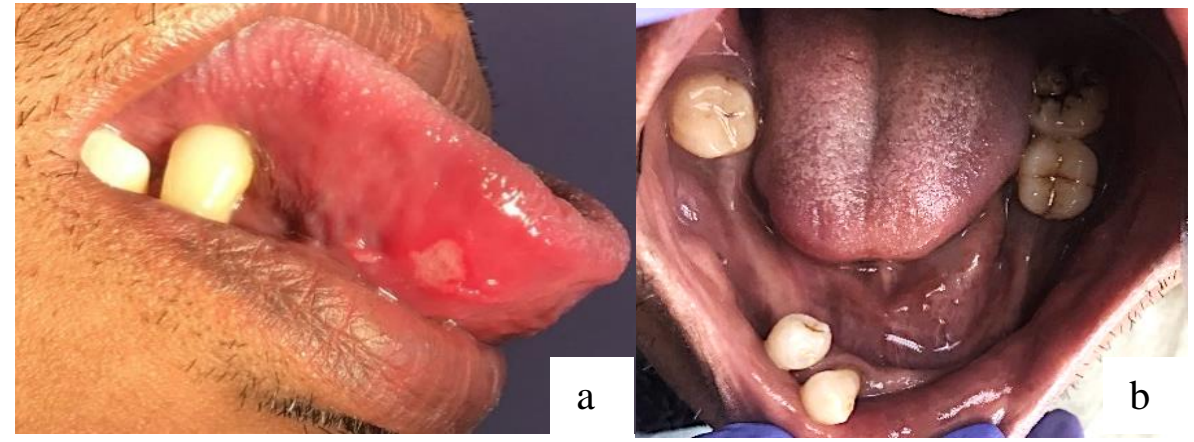

Gambar 1. Gambaran klinis lateral (a); oklusal (b)

Diagnosis ditegakkan berdasarkan pemeriksaan subjektif dan objektif pada pasien, yaitu ulser traumatik pada regio ventral lidah kanan dengan diagnosis banding stomatitis aptous rekuren. Pemeriksaan penunjang tidak dilakukan dengan alasan ketidakmampuan pasien. Penatalaksanaan berupa observasi dengan jangka waktu 1 minggu dan 1 bulan, edukasi perawatan kebersihan rongga mulut, medikasi yang terdiri dari pemberian obat kumur chlorhexidine gluconate 0,2\%, salep triamcinolone acetonide $0.1 \%$ dan multivitamin.

Pada saat kontrol 1 minggu pasien merasa sariawan sudah tidak sakit, namun lesi tersebut masih menunjukan proses penyembuhan. Perbaikan lesi terlihat pada saat pasien kontrol kunjungan 1 bulan (Gambar 2).

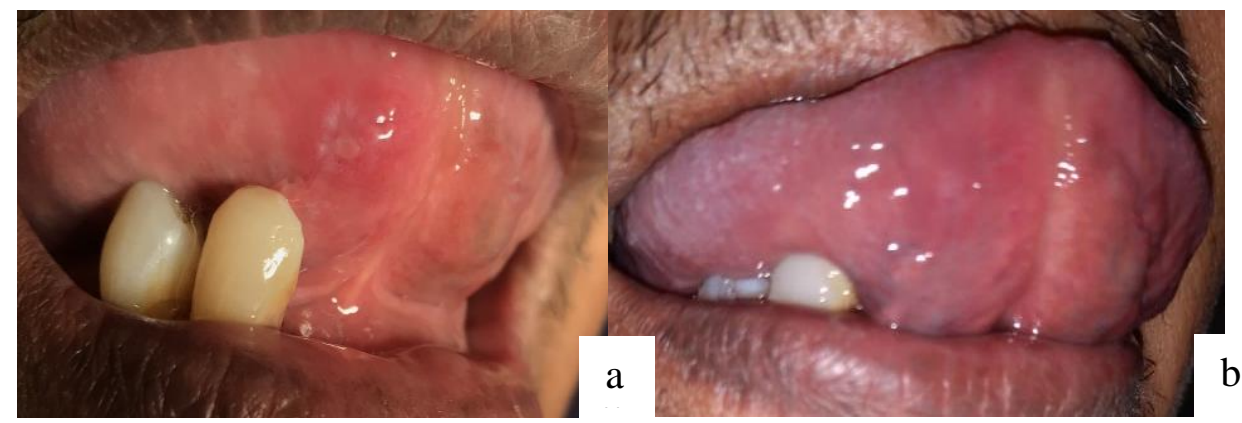

Gambar 3. Gambaran klinis pasien pada saat kontrol 1 minggu (a); kontrol 1 bulan (b)

\section{PEMBAHASAN}

Ulser merupakan hilangnya lapisan epitelium hingga melebihi membran basalis dan sampai mengenai lamina propria. Ulser di dalam rongga mulut yang disebabkan karena trauma disebut dengan ulser traumatik. Trauma di rongga mulut disebabkan oleh trauma fisik atau mekanik, termal dan kimia. Trauma fisik atau mekanik dapat terjadi akibat 
maloklusi, kontak antara mukosa dengan makanan atau gigi yang tajam, tergigit pada saat makan, berbicara atau tidur dan gigi palsu yang tidak dirawat. Trauma termal umunya terjadi pada individu yang mengkonsumsi makanan panas. Trauma kimia dapat terjadi akibat kecelakaan paparan bahan aktif di rongga mulut pada pasien yang menerima perawatan gigi. Bahan aktif yang digunakan adalah zat berbahaya atau bahan kaustik yang berbahaya jika terpapar langsung pada mukosa contohnya seperti penggunaan etsa, bonding pada prosedur perawatan gigi ${ }^{5,10}$.

Ulser traumatik pada umumnya terjadi karena etiologi yang tidak terduga. Ulser traumatik secara klinis dapat dibedakan menjadi ulser akut dan kronis. Ulser akut biasanya terasa sakit, dan terdapat riwayat trauma. Bentuk ulser tidak spesifik sangat tergantung dari penyebabnya dan memiliki dasar putih kekuningan dibatasi margin eritema. Ulser traumatik akut memiliki gambaran lesi yang menyerupai lesi stomatitis aftosa rekuren sedangkan ulser kronis biasanya tidak sakit atau adanya rasa sakit ringan dan terkadang pasien tidak mengetahui penyebab trauma. Pada ulser terlihat dasar putih kekuningan dan terdapat indurasi pada bagian margin. Penyembuhan akan terhambat jika masih terdapat iritasi di mukosa. Secara klinis lesi tersebut terlihat seperti karsinoma sel skuamosa oral dan ulser infeksius. Gambaran histopatologi ulser akut menunjukkan pada permukaan ulser terdapat jaringan fibrin dan banyak neutrofil. Dasar ulser mengandung kapiler yang mengalami dilatasi dan jaringan granulasi. Regenerasi epitel dimulai dari margin ulser, dengan sel epitel yang berproliferasi bergerak diantara dasar jaringan granulasi dan fibrin. Ulser kronis pada bagian dasarnya terdapat jaringan granulasi dan jaringan parut fibrosis. Regenerasi epitel akan terhambat jika masih terdapat iritasi pada daerah tersebut ${ }^{10,11}$. Ulser traumatik akan sembuh tanpa bekas luka dalam 7-10 hari, setelah menghilangkan faktor penyebabnya. Ulser traumatik yang masih terjadi lebih dari 10-12 hari, harus dilakukan biopsi untuk mencegah terjadinya kanker. Penegakan diagnosis dapat dilakukan melalui anamnesis, gambaran klinis dari lesi dan mengidentifikasi faktor etiologi trauma ${ }^{11,12}$.

Iritasi mekanis terjadi ketika suatu benda yang lebih keras bergesekan secara terus menerus pada mukosa. Kondisi diastema, kehilangan gigi, malposisi gigi mungkin saja tidak menimbulkan lesi klinis. Namun, hal ini merupakan faktor resiko yang dapat menyebabkan kontak langsung sehingga menimbulkan cedera potensial. Laporan kasus yang menghubungan kedua faktor tersebut masih terbatas. Faktor penyerta seperti kelainan parafungsional dan prostesa disimpulkan menjadi faktor penyebab ${ }^{13}$.

Diagnosis banding terkait dengan ulser traumatik adalah Stomatitis Aftosa Rekuren, yaitu ulser berbentuk bulat atau oval permukaannya ditutupi jaringan nekrotik yang disebut dengan pseudomembran, dan tampak cekung, margin ulser reguler berwarna eritem, secara klinis SAR dapat diklasifikasikan kedalam 3 tipe yaitu minor, mayor dan herpetiform. SAR minor berdiameter kurang dari $10 \mathrm{~mm}$, mayor lebih dari $1 \mathrm{~cm}$ dan herpetiform kurang dari $1 \mathrm{~mm}{ }^{12}$. Prinsip perawatan ulser traumatik adalah menghilangkan penyebab trauma, menghilangkan nyeri dan membantu penyembuhan lesi dengan pemberian obat antiinflamasi, seperti kortikosteroid secara topikal dan intralesional juga anastetikum lokal ${ }^{14}$. Diagnosis dan manajemen pasien dengan ulser di 
mulut memerlukan pendekatan sistematis berdasarkan prinsip anamnesis yang memadai, pemeriksaan klinis, pemeriksaan yang tepat disertai pemeriksaan penunjang, rencana perawatan, dan terapi yang sesuai. Ulser traumatik tidak dapat disembuhkan jika etiologinya tidak dihilangkan. Oleh karena itu observasi perawatan perlu dilakukan dalam kurun 1 bulan. Hal ini diperlukan dengan tujuan untuk meninjau pasien terhadap perbaikan dan respon pengobatan ${ }^{15}$.

\section{KESIMPULAN}

Ulser traumatik dapat disebabkan oleh gigi yang mengalami rotasi dan migrasi sehingga melukai jaringan lunak. Perawatan yang diberikan berupa terapi non farmakologi dan terapi farmakologi berupa pemberian obat kumur clorhexidine gluconate $0,2 \%$, salep triamcinolone acetonide $0,1 \%$ dan multivitamin dapat meredakan keluhan yang diderita.

\section{DAFTAR PUSTAKA}

1. Anura A. Traumatic oral mucosal lesions: a mini review and clinical update. Oral Health Dent Manag [Internet]. 2014 Jun;13(2):254-9. Available from: http://www.ncbi.nlm.nih.gov/pubmed/24984629

2. Shintaningrum L. Prevalensi Traumatik Ulser pada Mahasiswa Fakultas Kedokteran Gigi Universitas Jember yang Menjalani Perawatan Ortodontik Cekat [Internet]. 2013 [cited 2021 Jul 17]. Available from: http://repository.unej.ac.id/handle/123456789/2159

3. Suhartiningtyas D, Prahastuti N, Sari K. Insidensi Ulkus Traumatikus pada Pemakai Alat Ortodonsi Lepasan dan Ortodonsi Cekat. Insisiva Dent J Maj Kedokt Gigi Insisiva [Internet]. 2020;9(1):6-10. Available from: https://journal.umy.ac.id/index.php/di/article/view/7444

4. Akbari G, Dewi TS, Malik I. Traumatic ulcer distribution of patiens with removable orthodontic appliance in Orthodontics Clinics of Dental Specialist Program. Padjadjaran J Dent [Internet]. 2014 Mar 31 [cited 2021 Jul 17];26(1). Available from: http://jurnal.unpad.ac.id/pjd/article/view/26762

5. Mortazavi H, Safi Y, Baharvand M, Rahmani S. Diagnostic Features of Common Oral Ulcerative Lesions: An Updated Decision Tree. Int J Dent [Internet]. 2016 [cited 2021 Jul 17];2016:1-14. Available from: https://www.hindawi.com/journals/ijd/2016/7278925/

6. Regezi, Joseph A; Sciubba, James J; Jordan RCK. Oral Pathology: Clinical Pathologic Correlations. St. Louis, Mo. : Elsevier/Saunders; 2017. 23-7 p.

7. Jinbu Y, Demitsu T. Oral ulcerations due to drug medications. Jpn Dent Sci Rev [Internet]. $2014 \quad$ May;50(2):40-6. Available from: https://linkinghub.elsevier.com/retrieve/pii/S1882761613000811

8. Apriasari ML. The management of chronic traumatic ulcer in oral cavity. Dent $\mathbf{J}$ (Majalah Kedokt Gigi) [Internet]. 2012 Jun 1;45(2):68. Available from: http://ejournal.unair.ac.id/index.php/MKG/article/view/825 
9. Sunil A, Kurien J, Mukunda A, Bin Basheer A. Common Superficial Tongue Lesions. Vol. 23, 534 Indian Journal of Clinical Practice. 2013.

10. Mohanad J, Najm BDS. MDJ Prevalence of oral mucosal lesions in patients attending college of dentistry-Basrah University.

11. Akintoye SO, Greenberg MS. Recurrent Aphthous Stomatitis [Internet]. Vol. 58, Dental Clinics of North America. W.B. Saunders; 2014 [cited 2021 Jun 3]. p. 281-97. Available from: /pmc/articles/PMC3964366/

12. Herawati E, Dwiarie TA. Manajemen kasus ulserasi rongga mulut terkait trauma iatrogenik. J Kedokt Gigi Univ Padjadjaran. 2019 Aug 31;31(2):102-7.

13. Piemonte ED, Lazos J. Evidence for chronic mechanical irritation as a causative factor in oral cancer: application of Bradford Hill criteria. Transl Res Oral Oncol [Internet]. 2018 Jan 1;3:2057178X1879103. Available from: http://journals.sagepub.com/doi/10.1177/2057178X18791034

14. Belenguer-Guallar I, Jimenez-Soriano Y, Claramunt-Lozano A. Treatment of recurrent aphthous stomatitis. A literature review. J Clin Exp Dent [Internet]. 2014;e168-74. Available from: http://www.medicinaoral.com/odo/volumenes/v6i2/jcedv6i2p168.pdf

15. Thompson LD. Oral traumatic ulcer. Ear Nose Throat J [Internet]. 2011 Nov;90(11):518-34. http://www.ncbi.nlm.nih.gov/pubmed/22109918 